\title{
Electrochemical reduction of hydrogen peroxide on stainless steel ${ }^{\dagger}$
}

\author{
S PATRA and N MUNICHANDRAIAH* \\ Department of Inorganic and Physical Chemistry, Indian Institute of Science, Bangalore 560012 \\ e-mail: muni@ipc.iisc.ernet.in
}

\begin{abstract}
Electrochemical reduction of hydrogen peroxide is studied on a sand-blasted stainless steel (SSS) electrode in an aqueous solution of $\mathrm{NaClO}_{4}$. The cyclic voltammetric reduction of $\mathrm{H}_{2} \mathrm{O}_{2}$ at low concentrations is characterized by a cathodic peak at $-0.40 \mathrm{~V}$ versus standard calomel electrode (SCE). Cyclic voltammetry is studied by varying the concentration of $\mathrm{H}_{2} \mathrm{O}_{2}$ in the range from $0.2 \mathrm{mM}$ to $20 \mathrm{mM}$ and the sweep rate in the range from 2 to $100 \mathrm{mV} \mathrm{s}^{-1}$. Voltammograms at concentrations of $\mathrm{H}_{2} \mathrm{O}_{2}$ higher than $2 \mathrm{mM}$ or at high sweep rates consist of an additional current peak, which may be due to the reduction of adsorbed species formed during the reduction of $\mathrm{H}_{2} \mathrm{O}_{2}$. Amperometric determination of $\mathrm{H}_{2} \mathrm{O}_{2}$ at $-0.50 \mathrm{~V}$ vs SCE provides the detection limit of $5 \mu \mathrm{M} \mathrm{H}_{2} \mathrm{O}_{2}$. A plot of current density versus concentration has two segments suggesting a change in the mechanism of $\mathrm{H}_{2} \mathrm{O}_{2}$ reduction at concentrations of $\mathrm{H}_{2} \mathrm{O}_{2} \geq$ $2 \mathrm{mM}$. From the rotating disc electrode study, diffusion co-efficient of $\mathrm{H}_{2} \mathrm{O}_{2}$ and rate constant for reduction of $\mathrm{H}_{2} \mathrm{O}_{2}$ are evaluated.
\end{abstract}

Keywords. Electrochemical reduction of $\mathrm{H}_{2} \mathrm{O}_{2}$; stainless steel electrode; cyclic voltammetry; amperometry; rotating disc electrode.

\section{Introduction}

Hydrogen peroxide is an important ingredient in a wide range of industrial processes such as food processing (e.g. in the cold pasteurization of milk, wine aging, etc.), textile bleaching, cosmetics preparation, pharmaceutical manufacturing, etc. ${ }^{1} \mathrm{H}_{2} \mathrm{O}_{2}$ is also an intermediates during the reduction of oxygen in fuel cells. ${ }^{2}$ In fact, a challenging problem in fuel cell is the premature failure of the cell due to attack of the electrodes by $\mathrm{H}_{2} \mathrm{O}_{2}{ }^{3}$ The presence of stable dioxygen intermediates is an indication of intrinsic cell inefficiency in the reduction of oxygen at the cathode. In biological aerobic organisms, energy is derived from oxygen, which is susceptible to form $\mathrm{O}_{2}^{\circ}, \mathrm{OH}^{*}$ and $\mathrm{H}_{2} \mathrm{O}_{2}$, during its reduction by the electron transfer effect of mitochondria. ${ }^{4}$ These radicals (reactive oxygen species) cause different kinds of disorder in the body such as Alzheimer's, myocardial infarction, atherosclerosis, Parkinson's, etc. ${ }^{5}$ Hence, studies on $\mathrm{H}_{2} \mathrm{O}_{2}$ reduction are important in both chemistry and biology.

Electrochemical reduction of $\mathrm{H}_{2} \mathrm{O}_{2}$ at bare electrodes has been studied by different groups. ${ }^{6-12} \mathrm{On}$ Pt electrodes, $\mathrm{pH}$ and over-potential play important

\footnotetext{
${ }^{\dagger}$ Dedicated to the memory of the late Professor S K Rangarajan *For correspondence
}

roles on kinetics of $\mathrm{H}_{2} \mathrm{O}_{2}$ reduction. ${ }^{6} \mathrm{Ag}$ electrodes exhibit autocatalytic mechanism towards the reduction of $\mathrm{H}_{2} \mathrm{O}_{2}$ in acidic electrolyte. ${ }^{7}$ Somasundrum et $a l^{8}$ studied $\mathrm{H}_{2} \mathrm{O}_{2}$ reduction on $\mathrm{Cu}$ metal in $0 \cdot 1 \mathrm{M}$ phosphate buffer solution $(\mathrm{pH}=6 \cdot 7)$. They reported the mechanism of $\mathrm{H}_{2} \mathrm{O}_{2}$ reduction at ambient temperature and also the effect of dissolved oxygen on $\mathrm{H}_{2} \mathrm{O}_{2}$ reduction. $\mathrm{H}_{2} \mathrm{O}_{2}$ reduction was also studied on polycrystalline copper in borax buffer in the light of surface oxidation in presence of chloride ions in the electrolyte. ${ }^{9}$

There are also a few reports on reduction of $\mathrm{H}_{2} \mathrm{O}_{2}$ on modified electrodes. ${ }^{10-12} \mathrm{PdO}_{2}$ and $\mathrm{IrO}_{2}$ modified glassy carbon electrodes (GCE) were used as the electrodes for reduction of $\mathrm{H}_{2} \mathrm{O}_{2}$ in basic solution. ${ }^{10}$ The electrocatalytic activity of a graphite electrode modified by micro quantities of platinum metals $(\mathrm{Pd}$ or $\mathrm{Pt}+\mathrm{Pd}$ ) towards the $\mathrm{H}_{2} \mathrm{O}_{2}$ reduction were characterized by Dodevska et $a l$ and the electrode was used as a glucose biosensor. ${ }^{11} \mathrm{~A}$ conducting polymer modified by $\mathrm{Rh}$ mirco-particles on GCE was also used to detect $\mathrm{H}_{2} \mathrm{O}_{2}$, which was produced from the oxidation of glucose. ${ }^{12}$

Generally, noble metallic electrodes are used for studying electrochemical reactions because of their stability in the electrolytes. Non-noble metals are not preferred because they corrode in aqueous solutions. In the case of $\mathrm{H}_{2} \mathrm{O}_{2}$ reduction, copper was em- 
ployed and mechanistic studies were reported. ${ }^{8,9}$ There are no reports on electrochemical reduction of $\mathrm{H}_{2} \mathrm{O}_{2}$ on stainless steel (SS), to the best of authors' knowledge. In the present work, SS, which is a very common alloy, is used as the electrode material for electrochemical reduction of $\mathrm{H}_{2} \mathrm{O}_{2}$ in neutral $\mathrm{NaClO}_{4}$ electrolyte. Cyclic voltammetry, amperometry and rotating disc electrode (RDE) studies suggest that SS can be used for electrochemical determination of $\mathrm{H}_{2} \mathrm{O}_{2}$ at a concentration level as low as $5 \mu \mathrm{M}$.

\section{Experimental sections}

Analytical grade $\mathrm{H}_{2} \mathrm{SO}_{4}, \mathrm{NaClO}_{4}, \mathrm{NaOH}$ and $\mathrm{HCl}$ were purchased from Merck, Purified $\mathrm{H}_{2} \mathrm{O}_{2}(30 \%)$ was purchased also from Merck. A high purity commercial 304 grade stainless steel (SS) foil (thickness: $0.2 \mathrm{~mm}$ ) was used as the substrate for $\mathrm{H}_{2} \mathrm{O}_{2}$ reduction. A solution of $0.5 \mathrm{M} \mathrm{NaClO} \mathrm{Na}_{4}$ $(\mathrm{pH}=5.8)$ was usually used as the supporting electrolyte for $\mathrm{H}_{2} \mathrm{O}_{2}$. Some experiments were also conducted by varying $\mathrm{pH}$ of the electrolyte. All solutions were prepared in doubly distilled water. The electrolyte solutions were de-aerated by bubbling $\mathrm{N}_{2}$ for at least $30 \mathrm{~min}$ prior to electrochemical measurements. A glass cell of about $70 \mathrm{ml}$ capacities with suitable ground-glass joints to introduce a working electrode, Pt foil auxiliary electrodes, and a SCE was used for electrochemical experiments. All potential values are reported against SCE.

A SS sheet was subjected to sand-blasting to generate a noticeable rough surface and washed copiously using a detergent followed by a mild etching in dilute $\mathrm{H}_{2} \mathrm{SO}_{4}$. A foil of $7 \mathrm{~mm}$ width and $6 \mathrm{~cm}$ in length was sectioned out of a sand-blasted SS sheet, $1.4 \mathrm{~cm}^{2}$ areas at one of the ends was exposed to the electrolyte and the rest of its length was used as a tag for taking electrical contacts. Hereafter, sandblasted SS electrode is hereafter referred to as SSS. The SSS substrate was again washed thoroughly, rinsed with acetone and dried in vacuum at ambient temperature for about $30 \mathrm{~min}$ for further studies. Geometric area of the electrode was used for calculation of current density $\left(\mathrm{mA} \mathrm{cm}^{-2}\right)$.

Cyclic voltammetry and amperometry experiments were carried out using an EG\&G PARC potentiostat/galvanostat Versastat II or Eco Chemie potentiostat/galvanostat model Autolab 30. RDE experiments were carried out using Eco Chemie RDE model Rotator 188. The electrode tip was made of SS. Experiments were carried out with rotation speed in the range from 100 to $5000 \mathrm{rpm}$.

\section{Results and discussions}

\subsection{Cyclic voltammetry}

Cyclic voltammogram of a SSS electrode recorded in $0.5 \mathrm{M} \mathrm{NaClO}_{4}+5 \mathrm{mM} \mathrm{H}_{2} \mathrm{O}_{2}$ at $5 \mathrm{mV} \mathrm{s}^{-1}$ in the potential range from -0.1 to $-0.7 \mathrm{~V}$ is shown in figure 1. For comparison purpose, cyclic voltammogram recorded in $0.5 \mathrm{M} \mathrm{NaClO}_{4}$ in the absence of $\mathrm{H}_{2} \mathrm{O}_{2}$ is also presented. In the absence of $\mathrm{H}_{2} \mathrm{O}_{2}$, cyclic voltammogram (figure 1 curve (i)) does not exhibit any current peak suggesting that SSS is stable in the potential range studied. In the presence of $\mathrm{H}_{2} \mathrm{O}_{2}$ in the electrolyte, however, current starts increasing at $-0.1 \mathrm{~V}$ (figure 1 curve (ii)) in the forward sweep. On further extending the sweep in the negative direction, a reduction current peak (P1) appears at $-0.404 \mathrm{~V}$. On reversing the direction of sweep at $-0.7 \mathrm{~V}$, no oxidation current peak is observed. The appearance of an irreversible reduction peak in the presence of $\mathrm{H}_{2} \mathrm{O}_{2}$ (figure 1 curve (ii)) and absence of peak in the absence of $\mathrm{H}_{2} \mathrm{O}_{2}$ (figure 1 curve (i)) suggest that the current peak $\mathrm{P} 1$ is due to reduction of $\mathrm{H}_{2} \mathrm{O}_{2}$. In order to examine the effect of roughness of SSS surface due to sand blasting on the reduction of $\mathrm{H}_{2} \mathrm{O}_{2}$, a cyclic voltammogram recorded using a plain $\mathrm{SS}$ is shown in figure 1

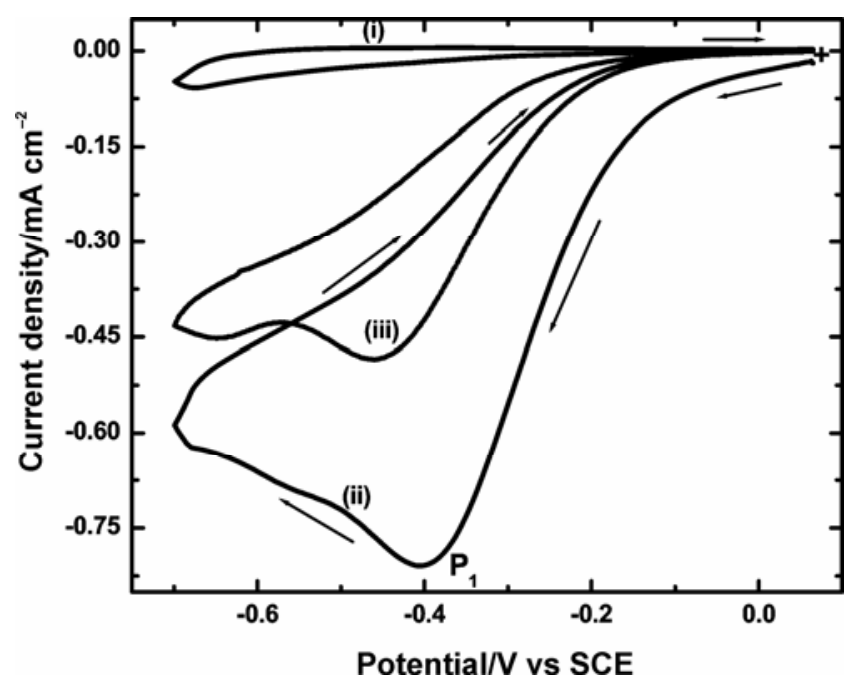

Figure 1. Cyclic voltammograms of SSS electrode in $0.5 \mathrm{M} \mathrm{NaClO}_{4}$ in the absence of $\mathrm{H}_{2} \mathrm{O}_{2}$ (i) and presence of $5 \mathrm{mM} \mathrm{H} \mathrm{O}_{2}$ (ii); and voltammogram of $\mathrm{SS}$ electrode in $0 \cdot 5 \mathrm{M} \mathrm{NaClO}_{4}+5 \mathrm{mM} \mathrm{H}_{2} \mathrm{O}_{2}$ (iii). Sweep rate: $5 \mathrm{mV} \mathrm{s}^{-1}$. 

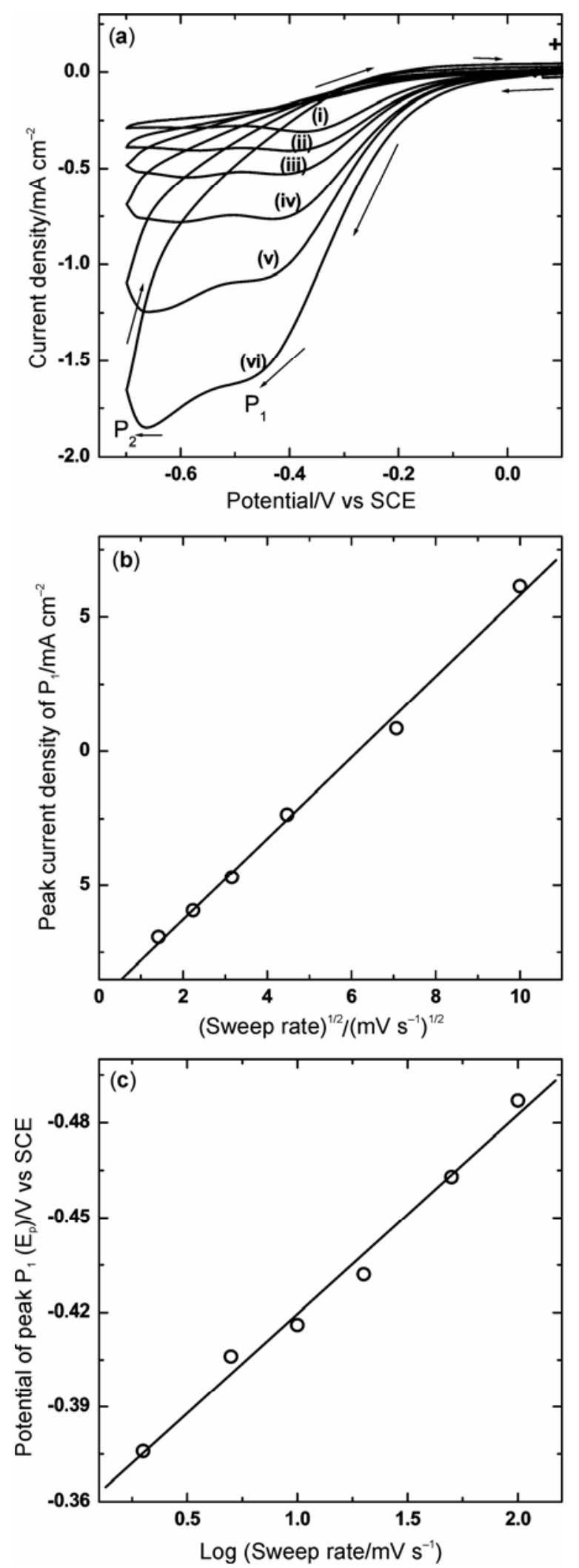

Figure 2. (a). Cyclic voltammograms of SSS electrode in $0.5 \mathrm{M} \mathrm{NaClO}_{4}+3 \mathrm{mM} \mathrm{H}_{2} \mathrm{O}_{2}$ at a sweep rate of 2 (i), 5 (ii), 10 (iii), 20 (iv), 50 (v) and $100 \mathrm{mV} \mathrm{s}^{-1}$ (vi); (b). The peak current density of $P_{1}$ versus (sweep rate) ${ }^{1 / 2}$ of data presented in (a); and (c) potential of peak $P_{1}$ versus log (sweep rate). (curve (iii)). It is observed that the voltammograms on SSS and SS are similar in shape and the peak current density on SSS is $60 \%$ greater than on SS (figure 1). This indicates a $60 \%$ increase in surface area of SSS due to sand-blasting. These results further suggest that basically the SS surface facilitates the electrochemical reduction of $\mathrm{H}_{2} \mathrm{O}_{2}$. For further studies, SSS was used. A SSS electrode was repeatedly cycled in $0.5 \mathrm{M} \mathrm{NaClO}_{4}+4 \mathrm{mM} \mathrm{H}_{2} \mathrm{O}_{2}$ at $5 \mathrm{mV} \mathrm{s}^{-1}$, to examine its stability and activity towards reduction of $\mathrm{H}_{2} \mathrm{O}_{2}$. Cyclic voltammograms (not shown), similar to figure 1 curve (ii), were reproducible with very marginal decrease in peak current during ten cycles. Although the supporting electrolyte, namely, $0.5 \mathrm{M} \mathrm{NaClO}_{4}$ is not a buffer solution and the surface concentration of $\mathrm{OH}^{-}$ions increases during $\mathrm{H}_{2} \mathrm{O}_{2}$ reduction by cyclic voltammetry, the voltammograms are not affected to a considerable extent. Buffer solutions are not used as the supporting electrolytes to avoid any adsorption effects on the SSS surface. Thus SSS is considered to retain its electrochemical activity for reduction of $\mathrm{H}_{2} \mathrm{O}_{2}$ without undergoing fouling or poisoning due to any intermediate species adsorbed during the reduction process in the supporting electrolyte.

Cyclic voltammograms of SSS electrode in $0.5 \mathrm{M}$ $\mathrm{NaClO}_{4}+3 \mathrm{mM} \mathrm{H} \mathrm{H}_{2} \mathrm{O}_{2}$ were recorded at different sweep rates $(v)$ and the data are shown in figure 2(a). At low sweep rates (figure 2(a) curve (i)), there is single reduction current peak (P1) appearing at about $-0.376 \mathrm{~V}$. As the sweep rate increases, however, another reduction peak (P2) starts appearing and it becomes a clear, sharp peak at high sweep rates. At $100 \mathrm{mV} \mathrm{s}^{-1}$, for instance, the peak P2 is clearly seen at $-0.66 \mathrm{~V}$. The appearance of $\mathrm{P} 2$ is likely to be due to reduction of intermediate species adsorbed on the SSS surface during $\mathrm{H}_{2} \mathrm{O}_{2}$ reduction, as discussed below. The variation of peak current density (Ip 1 ) of $\mathrm{P} 1$ with $v^{1 / 2}$ is shown in figure 2(b). There is a linear increase of Ip 1 with $v^{1 / 2}$, suggesting that the reduction of $\mathrm{H}_{2} \mathrm{O}_{2}$ on SSS is diffusion controlled. The relationship between $E_{p}$ and sweep rate (v) for an irreversible reaction is given by (1): ${ }^{13}$

$$
E_{p}=k+\left(2 \cdot 3 R T /\left(2 n_{a} \alpha_{a} F\right)\right) \log v,
$$

where $k$ is a constant, $\alpha_{a}$ is transfer co-efficient, $n_{a}$ is number of electrons transferred up to the rate determining step of the reaction and the other symbols have their usual meanings. The product $(2 \cdot 3 R T /$ $\left.\left(n_{a} \alpha_{a} F\right)\right)$ is equivalent to the Tafel slope, which can 
be evaluated from (1). A plot of $E_{p}$ vs $\log v$ is shown in figure 2(c). The value of slope of this plot obtained is $0.12 \mathrm{~V}$. Thus, the Tafel slope is $0.24 \mathrm{~V}$. This value is greater than $0 \cdot 12 \mathrm{~V}$, which is generally expected for a single electron transfer process (assuming transfer coefficient $(\alpha)$ equal to $0 \cdot 5)$. As the electrochemical reduction of $\mathrm{H}_{2} \mathrm{O}_{2}$ on SSS appears to have a complicated mechanism as discussed later, $\alpha$ is calculated from cyclic voltammograms using (2).

$$
E_{p}-E_{p / 2}=1 \cdot 857 R T /(\alpha n F),
$$

where $E_{p / 2}$ is the potential on rising part of the voltammogram corresponding to one half the peak current, $\mathrm{n}$ is the number of electron in rate determining step and the rest of the symbols have their usual meanings. The value of $\alpha$ obtained is 0.32 . As the value of Tafel slope is high and the value of $\alpha$ is low, the mechanism of $\mathrm{H}_{2} \mathrm{O}_{2}$ reduction appears to be complex.

Cyclic voltammograms of an SSS electrode were recorded in $0.5 \mathrm{M} \mathrm{NaClO}_{4}$ solution containing $\mathrm{H}_{2} \mathrm{O}_{2}$ at various concentrations. Some of the voltammograms are presented in figure 3(a). There is an increase in current with increasing concentration of $\mathrm{H}_{2} \mathrm{O}_{2}$. At low concentrations of $\mathrm{H}_{2} \mathrm{O}_{2}$, single reduction peak $P_{1}$ appears at about $-0.5 \mathrm{~V}$ (figure 3(a) curve (ii)). However, the second peak $\mathrm{P}_{2}$ is observed at high concentration of $\mathrm{H}_{2} \mathrm{O}_{2}$ (figure 3(a) curve (iv)). A plot of $I_{p 1}$ versus concentration is shown in figure 3(b). There is a linear increase of $I_{p 1}$ with an increase in concentration of $\mathrm{H}_{2} \mathrm{O}_{2}$. These results suggested that SSS is an appropriate electrode material for studying electrochemical reduction of $\mathrm{H}_{2} \mathrm{O}_{2}$.

Studies on mechanism of electrochemical reduction of $\mathrm{H}_{2} \mathrm{O}_{2}$ on different metallic electrodes occupied interest in the literature. Mechanistic studies were conducted on polycrystalline copper in a borax buffer electrolyte. ${ }^{9}$ Copper electrode was shown to consist of $\mathrm{CuO}$ and $\mathrm{Cu}_{2} \mathrm{O}$ layers. The oxides of $\mathrm{Cu}$ are considered to catalyse the reduction of $\mathrm{H}_{2} \mathrm{O}_{2}$. The proposed mechanism involves the chemical oxidation of $\mathrm{Cu}_{2} \mathrm{O}$ by $\mathrm{H}_{2} \mathrm{O}_{2}$ :

$$
\mathrm{Cu}_{2} \mathrm{O}+\mathrm{H}_{2} \mathrm{O}_{2} \rightarrow \mathrm{CuO}+\mathrm{H}_{2} \mathrm{O}
$$

which is followed by electrochemical reduction of $\mathrm{CuO}$ to $\mathrm{Cu}_{2} \mathrm{O}$ as

$$
\mathrm{CuO}+\mathrm{H}_{2} \mathrm{O}+2 e^{-} \rightarrow \mathrm{Cu}_{2} \mathrm{O}+2 \mathrm{OH}^{-} .
$$

Thus, the $\mathrm{H}_{2} \mathrm{O}_{2}$ reduction occurs indirectly with $\mathrm{Cu}_{2} \mathrm{O}$ acting as a redox carrier. Cyclic voltammetric peak currents correspond to the reduction of $\mathrm{CuO}$. Furthermore, it was considered that $\mathrm{CuO}$ surface inhibits direct electron transfer to $\mathrm{H}_{2} \mathrm{O}_{2}$ for reducing the latter. Rate of the reaction was considered to be determined by the surface coverage of $\mathrm{CuO}$.

Similar to the above mechanism of reduction of $\mathrm{H}_{2} \mathrm{O}_{2}$ mediated by $\mathrm{CuO}$, a mechanism mediated by $\mathrm{IrO}_{2}$ on glassy carbon electrode was also proposed. ${ }^{10}$ An auto catalytic mechanism on Ag electrode was
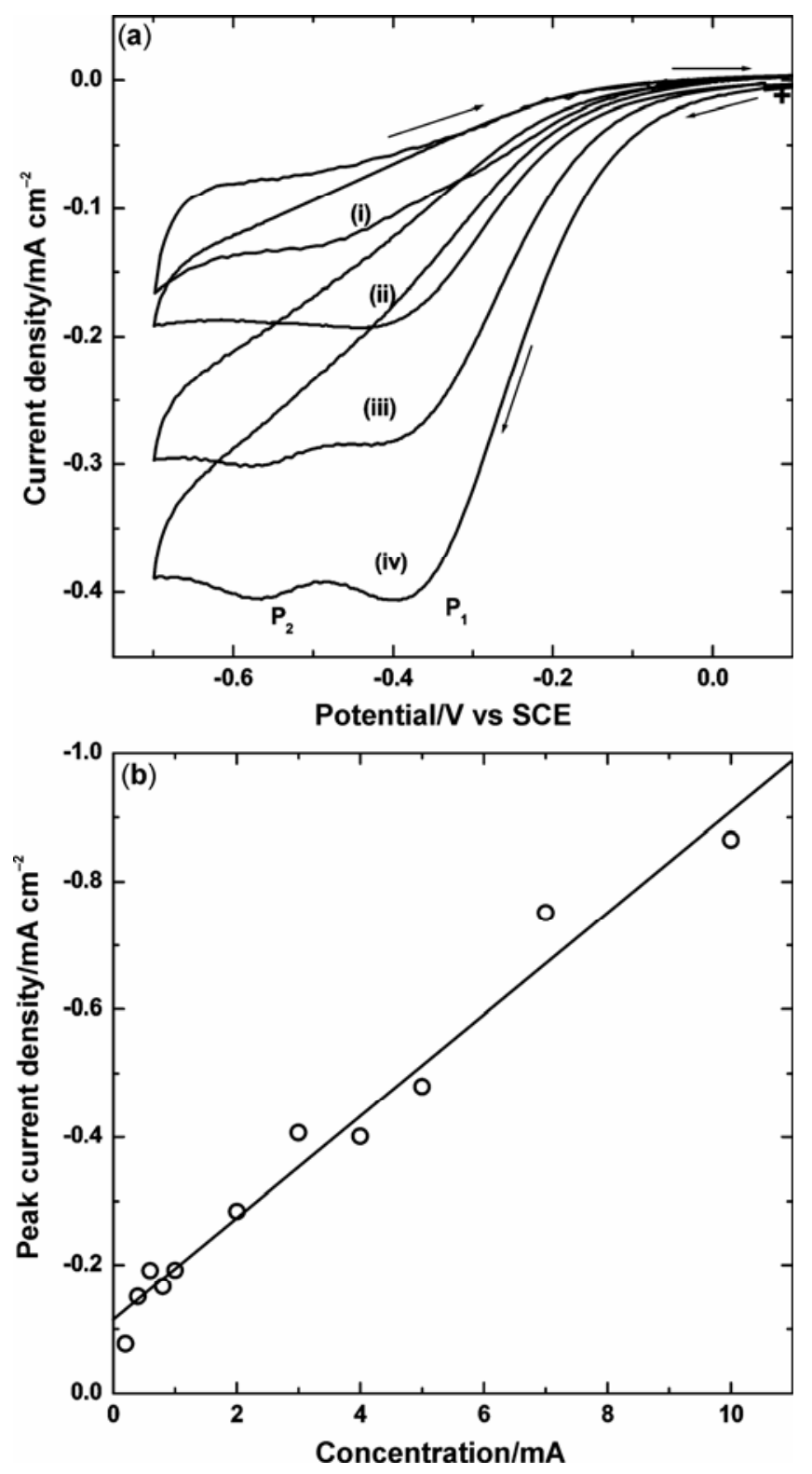

Figure 3. (a) Cyclic voltammograms of SSS electrode at a sweep rate of $5 \mathrm{mV} \mathrm{s}^{-1}$ in $0.5 \mathrm{M} \mathrm{NaClO}_{4}$ with 0.8 (i), 1 (ii), 2 (iii), 3 (iv), $4 \mathrm{mM}$ (v) of $\mathrm{H}_{2} \mathrm{O}_{2}$; and (b) peak current density of $P_{1}$ vs concentration of $\mathrm{H}_{2} \mathrm{O}_{2}$. 
proposed. ${ }^{7}$ The autocatalytic mechanism involving adsorbed $\mathrm{OH}_{\text {ads }}$ species was shown operative at potentials of about $-0.3 \mathrm{~V}$ vs MSE $\left(\mathrm{Hg} / \mathrm{HgSO}_{4}, \mathrm{~K}_{2} \mathrm{SO}_{4}\right.$ (sat)) reference electrode, whereas the normal mechanism is operative at $-0.4 \mathrm{~V}$ versus MSE.

In the present study of $\mathrm{H}_{2} \mathrm{O}_{2}$ reduction on SSS, the mechanism of the reaction is different from the above discussion. Although the SSS substrate is subjected to acidic etching to remove surface oxide layers, it is likely that the surface is covered with an oxide layer (perhaps chromium oxide) before it is used for electrochemical experiments. Nevertheless, the cyclic voltammograms of SSS in $\mathrm{H}_{2} \mathrm{O}_{2}$-free $\mathrm{NaClO}_{4}$ electrolyte (figure 1 curve (i)) indicate the absence of any reduction current peaks. Thus, reduction of $\mathrm{H}_{2} \mathrm{O}_{2}$ on SSS is not mediated by surface oxide layers, unlike mediation of the reduction by $\mathrm{CuO}$ present on $\mathrm{Cu}$.

A mechanism involving decomposition (or disproportionation) of $\mathrm{H}_{2} \mathrm{O}_{2}$ leading to the formation of $\mathrm{O}_{2}$ followed by the electrochemical reduction of $\mathrm{O}_{2}$ is also reported in the literature. ${ }^{14,15}$

$$
\begin{aligned}
& 2 \mathrm{H}_{2} \mathrm{O}_{2} \rightarrow 2 \mathrm{H}_{2} \mathrm{O}+\mathrm{O}_{2} \\
& \mathrm{O}_{2}+4 \mathrm{H}^{+}+4 e^{-}=2 \mathrm{H}_{2} \mathrm{O} .
\end{aligned}
$$

In order to examine the possibility of the above reaction, cyclic voltammograms of the SSS electrode were recorded in $\mathrm{NaClO}_{4}$ saturated with $\mathrm{O}_{2}$ gas. A peak corresponding to the reduction of $\mathrm{O}_{2}$ appeared at about $-0.2 \mathrm{~V}$, which is more positive to $-0.40 \mathrm{~V}$ observed for $\mathrm{H}_{2} \mathrm{O}_{2}$ reduction (figure 1 curve (ii)). Therefore disproportionation pathway for $\mathrm{H}_{2} \mathrm{O}_{2}$ reduction is ruled out. The possible mechanism, therefore, is as follows:

The direct reduction of $\mathrm{H}_{2} \mathrm{O}_{2}$ in a slightly acidic medium $(\mathrm{pH}=5 \cdot 8)$ :

$$
\mathrm{H}_{2} \mathrm{O}_{2}+2 \mathrm{H}^{+}+2 e^{-} \rightarrow 2 \mathrm{H}_{2} \mathrm{O},
$$

can be considered to occur through the formation of adsorbed $\mathrm{OH}_{\mathrm{ad}}$ species.

$$
\begin{aligned}
& \mathrm{H}_{2} \mathrm{O}_{2 \text { (bulk) }} \rightarrow \mathrm{H}_{2} \mathrm{O}_{2 \text { (surface) }} \\
& \mathrm{H}_{2} \mathrm{O}_{2 \text { (surface) }}+e^{-} \rightarrow \mathrm{OH}_{\mathrm{ad}}+\mathrm{OH}^{-} \\
& \mathrm{OH}^{-}+\mathrm{H}^{+} \rightarrow \mathrm{H}_{2} \mathrm{O} \\
& \mathrm{OH}_{\mathrm{ad}}+e^{-} \rightarrow \mathrm{OH}^{-}
\end{aligned}
$$

$$
\mathrm{OH}_{\mathrm{ad}}+\mathrm{H}^{+}+e^{-} \rightarrow \mathrm{H}_{2} \mathrm{O} \text {. }
$$

Diffusion of $\mathrm{H}_{2} \mathrm{O}_{2}$ from bulk to the electrode surface (step 8) followed by electrontransfer steps (reactions 9 and 11) is expected to result in the cyclic voltammetric peak current. $\mathrm{OH}^{-}$ion thus formed combine with $\mathrm{H}+$ ion (reaction 10) at the electrode to produce the reaction product, namely, $\mathrm{H}_{2} \mathrm{O}$. Alternately, $\mathrm{OH}_{\mathrm{ad}}$ can simultaneously accept an electron and $\mathrm{H}^{+}$ ion producing $\mathrm{H}_{2} \mathrm{O}$ in reaction 12 . It is likely that at low sweep rates and low concentrations, where a single voltammetric peak is observed, steps 10-11 are appropriate to complete the overall reduction of $\mathrm{H}_{2} \mathrm{O}_{2}$. At high sweep rates and high concentrations of $\mathrm{H}_{2} \mathrm{O}_{2}$, step 12 also occurs together with step 9-11, due to high surface coverage of OHad. The step 12 is likely to be responsible for the presence of second voltammetric peak $\left(P_{2}\right)$ at $-0.66 \mathrm{~V}$.

\subsection{Amperometry}

In an amperometry experiment, current flowing through an SSS electrode at $-0.50 \mathrm{~V}$ was measured as a function of concentration of $\mathrm{H}_{2} \mathrm{O}_{2}$ in $0.5 \mathrm{M}$ $\mathrm{NaClO}_{4}$ (figure 4(a)). The electrolyte was stirred uniformly by a PTFE covered magnetic bar during the experiment. A wide concentration range from $5 \mu \mathrm{M}$ to $20 \mathrm{mM}$ was studied. Subsequent to each addition of $\mathrm{H}_{2} \mathrm{O}_{2}$, the SSS electrode shows a rapid response in increasing the current. However, current tends to decrease with time at a given concentration of $\mathrm{H}_{2} \mathrm{O}_{2}$ in the electrolyte due to adsorption of the reaction intermediate as discussed in cyclic voltammetric studies. Current was measured 5 min after each addition of $\mathrm{H}_{2} \mathrm{O}_{2}$ (figure $4 \mathrm{a}$ ), and the amperometric current density measured from figure $4(\mathrm{a})$ is shown in figure 4(b) as a function of concentration of $\mathrm{H}_{2} \mathrm{O}_{2}$. There are two linear segments of the data. The first segment between $5 \mu \mathrm{M}$ and $2.5 \mathrm{mM}$ is steeper than the second segment between $2.5 \mathrm{mM}$ and $20 \mathrm{mM}$. Appearance of two segments is attributed to differences in surface coverage of $\mathrm{OH}_{\mathrm{ad}}$ (reaction 9) at low and high concentration ranges of $\mathrm{H}_{2} \mathrm{O}_{2}$. Thus, the rate of $\mathrm{H}_{2} \mathrm{O}_{2}$ reduction in lower concentration range is higher than the rate in higher concentration range. The rate of reduction is given by

$$
i=n F k \theta C^{0} \text {, }
$$

where $i$ is the current density, $k$ the rate constant, $\theta$ the surface coverage by adsorbed species and $C^{0}$ the 
concentration of $\mathrm{H}_{2} \mathrm{O}_{2}$ in the electrolyte. The values of $k \theta$ obtained at $-0.50 \mathrm{~V}$ are $1.15 \times 10^{-2}$ and $1.02 \times 10^{-3} \mathrm{~cm} \mathrm{~s}^{-1}$, respectively, for low and high concentration regions. This study supports the cyclic voltammteric study, where two different processes depending on concentration range and sweep rate range are possible. The linear segment in figure 4(b) in lower concentration range is likely to be due to the direct addition of electron to $\mathrm{H}_{2} \mathrm{O}_{2}$ (reaction 9)
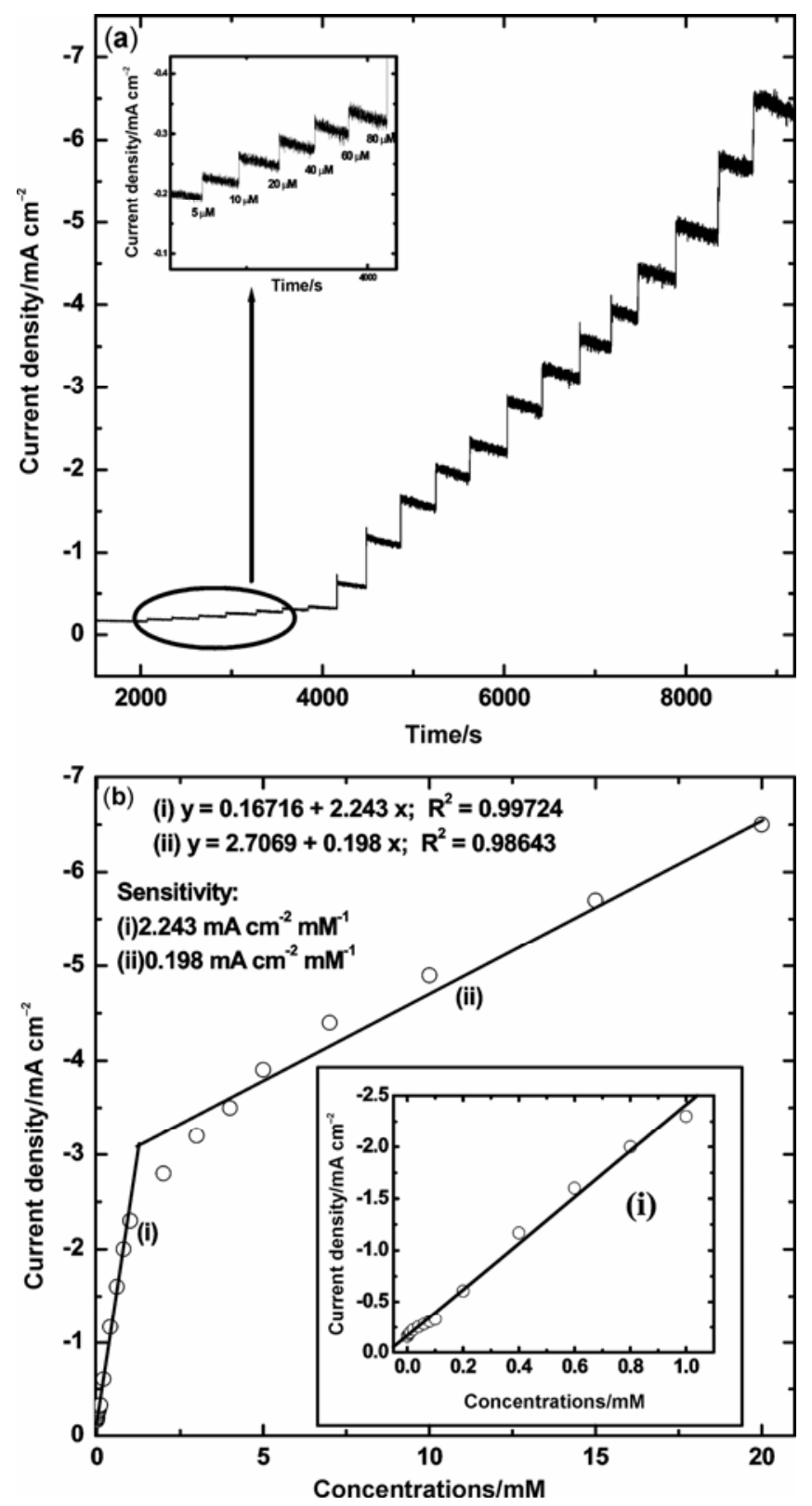

Figure 4. (a) Amperometry of SSS electrode in $0.5 \mathrm{M}$ $\mathrm{NaClO}_{4}$ with addition of different amounts of $\mathrm{H}_{2} \mathrm{O}_{2}$. The data corresponding to low concentration range are shown as the inset in an expanded scale; and (b) current density versus concentration of $\mathrm{H}_{2} \mathrm{O}_{2}$ added (from a). The low concentration data are magnified and shown in the inset. or to $\mathrm{OH}_{\mathrm{ad}}$ (reaction 11) because of low surface coverage. However at high concentrations of $\mathrm{H}_{2} \mathrm{O}_{2}$, the surface coverage is large and therefore the electron transfer and also the addition of $\mathrm{H}^{+}$to $\mathrm{OH}_{\mathrm{ad}}$ can take place simultaneously (reaction 11).

\subsection{Effect of electrolyte $\mathrm{pH}$}

The influence of $\mathrm{pH}$ of $\mathrm{NaClO}_{4}$ on the reduction of $\mathrm{H}_{2} \mathrm{O}_{2}$ was examined. For this purpose $0.5 \mathrm{M} \mathrm{NaClO}_{4}$ $(\mathrm{pH}=5.8)$ was prepared and $\mathrm{pH}$ was adjusted to the required value by adding dilute $\mathrm{NaOH}$ or dilute $\mathrm{HClO}_{4}$. Cyclic voltammogram of an SSS in electrolytes consisting of $4 \mathrm{mM}$ of $\mathrm{H}_{2} \mathrm{O}_{2}$ are shown in figure 5. At low $\mathrm{pH}$ value $(\mathrm{pH}=1.5)$, no peak was observed probably due to the decomposition of $\mathrm{H}_{2} \mathrm{O}_{2}$. At $\mathrm{pH}=2 \cdot 5$, there are two reduction peaks $\left(P_{1}\right.$ and $P_{2}$ ) with peak potentials at -0.17 and $-0.50 \mathrm{~V}$, respectively. When $\mathrm{pH}$ is increased to $5 \cdot 8$, there is a shift in peak potentials to -0.40 and $-0.66 \mathrm{~V}$, respectively, for $P_{1}$ and $P_{2}$. The variation of potential of a $\mathrm{H}^{+}$ion-dependent process (reaction 7) is $0.059 \mathrm{~V}$ per unit $\mathrm{pH}$ according to the Nernst equation. For the increase of $\mathrm{pH}$ from 2.5 to $5 \cdot 8$, a shift of potential in the negative direction by $0.195 \mathrm{~V}$ is expected. Accordingly, there is a large shift in potentials of peaks $P_{1}$ and $P_{2}$ by changing the $\mathrm{pH}$ from $2 \cdot 5$ to $5 \cdot 8$. Single cyclic voltammetric peaks are observed in electrolytes of $\mathrm{pH}$ values 10 and 11 (figure $5 \mathrm{~d}$ and e). A plot of $I_{\mathrm{p} 1}$ versus $\mathrm{pH}$ (figure 5f) shows that the rate of $\mathrm{H}_{2} \mathrm{O}_{2}$ reduction is maximum at $\mathrm{pH}=5 \cdot 8$, and it decreases by either decreasing or increasing $\mathrm{pH}$ from $5 \cdot 8$.

\subsection{Rotating disc electrode studies}

Experiments were carried out by subjecting a RDE made of SS to a linear sweep voltammetry at a sweep rate of $5 \mathrm{mV} \mathrm{s}^{-1}$ in $0.5 \mathrm{M} \mathrm{NaClO}_{4}$ consisting of $\mathrm{H}_{2} \mathrm{O}_{2}$ at varying concentrations. The speed of RDE was varied from 100 to $3000 \mathrm{rpm}$. A typical set of data obtained in $0.5 \mathrm{M} \mathrm{NaClO}+1 \mathrm{mM} \mathrm{H}_{2} \mathrm{O}_{2}$ with several rotation speeds are shown in figure 6(a). Current starts increasing at about $-0.4 \mathrm{~V}$ and reaches a plateau in the potential range between -0.65 and $-0.85 \mathrm{~V}$. The plateau region commences at less negative potential if the speed is low, whereas it commences at more negative potential if the RDE speed is high. There is an increase in plateau current with increasing speed of rotation. The plateau current, which is generally known as limiting current 

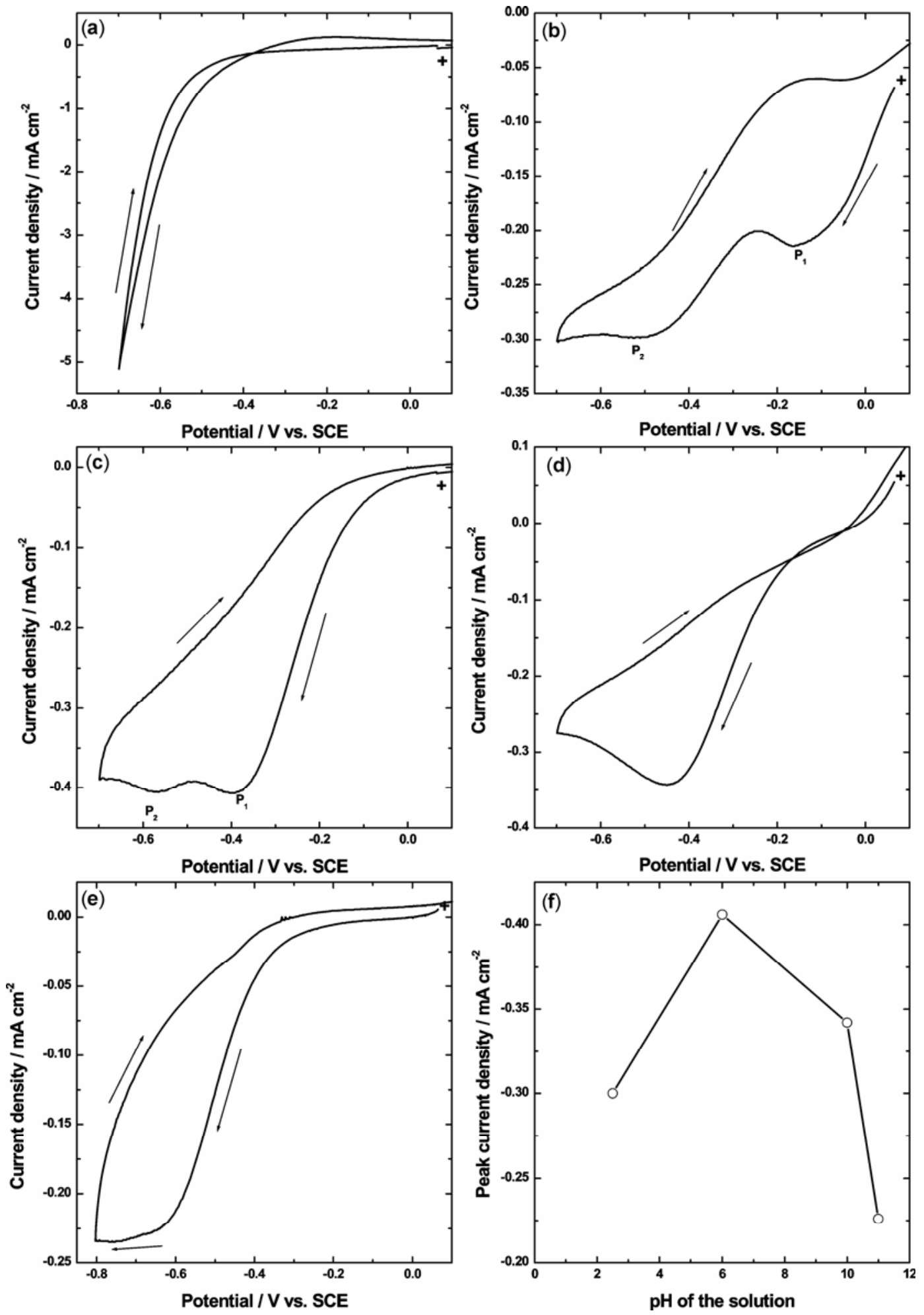

Figure 5. Cyclic voltammograms of SSS in $3 \mathrm{mM} \mathrm{H}_{2} \mathrm{O}_{2}$ and $0.5 \mathrm{M} \mathrm{NaClO}_{4}$ of $\mathrm{pH}$ (a) 1.5 , (b) $2 \cdot 5$, (c) $5 \cdot 8$, (d) 10.0 and (e) 11.0 and (f) current density of peak $P_{1}$ versus $\mathrm{pH}$ of the solution.

density $\left(i_{L}\right)$ is related to rotation rate by Levich equation: ${ }^{17}$

$$
i_{L}=0 \cdot 62 n F A D^{1 / 2} v^{-1 / 6} C^{0} \omega^{1 / 2},
$$

where $v$ is kinematic viscosity of the medium, $\omega$ $(=2 \pi f)$ is angular velocity, $f$ is frequency in revolution per second and other symbols have their usual significance. Plots of $I_{L}$ versus $f^{1 / 2}$ were constructed 

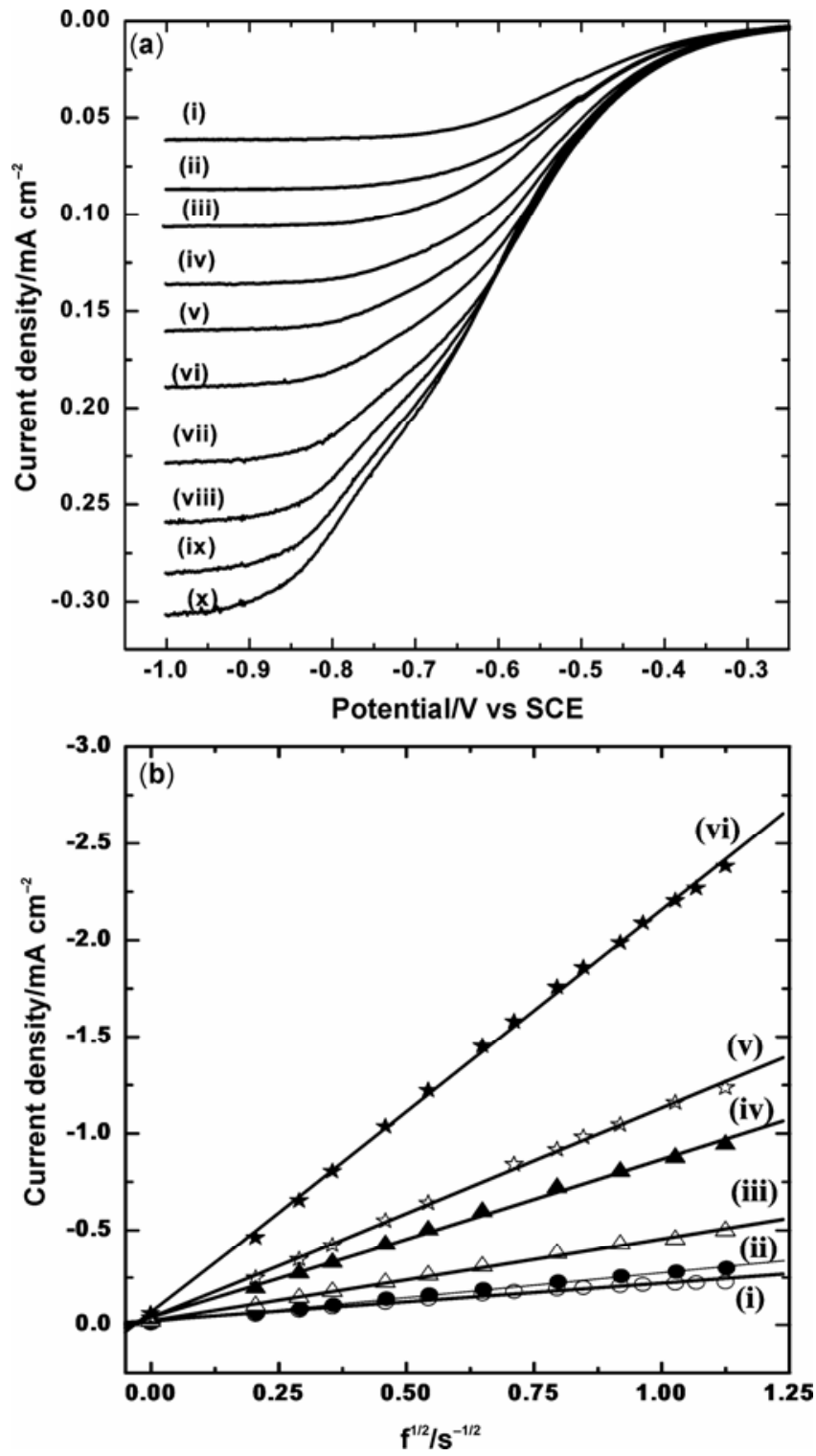

Figure 6. (a). Linear sweep voltammograms of SS rotating disk electrode in $0.5 \mathrm{M} \mathrm{NaClO} 4+1 \mathrm{mM}$ of $\mathrm{H}_{2} \mathrm{O}_{2}$ with speed of rotation of 100 (i), 200 (ii), 300 (iii), 500 (iv), 700 (v), 1000 (vi), 1500 (vii), 2000 (viii), 2500 (ix), $3000 \mathrm{rpm}(\mathrm{x})$; and (b). Levich plot for $\mathrm{H}_{2} \mathrm{O}_{2}$ concentration of $0 \cdot 8$ (i), 1 (ii), 2 (iii), 3 (iv), 5 (v), $10 \mathrm{mM}$ (vi).

from the data measured in electrolytes of different concentrations of $\mathrm{H}_{2} \mathrm{O}_{2}$ and presented in figure 6(b). All plots are linear suggesting that the RDE data follow Levich relationship for all concentrations studied. Adsorption effects are considered to be absent due to high rotation speeds of $\mathrm{RDE}$ and therefore $\theta$ is not included in (14). From the slopes of the plots and (14), the values of apparent diffusion coefficient (D) of $\mathrm{H}_{2} \mathrm{O}_{2}$ are calculated and the average value is about $1.53 \times 10^{-6} \mathrm{~cm}^{2} \mathrm{~s}^{-1}$. These studies further confirm that SS substrate is quite suitable for studying the electrochemical reduction of $\mathrm{H}_{2} \mathrm{O}_{2}$.

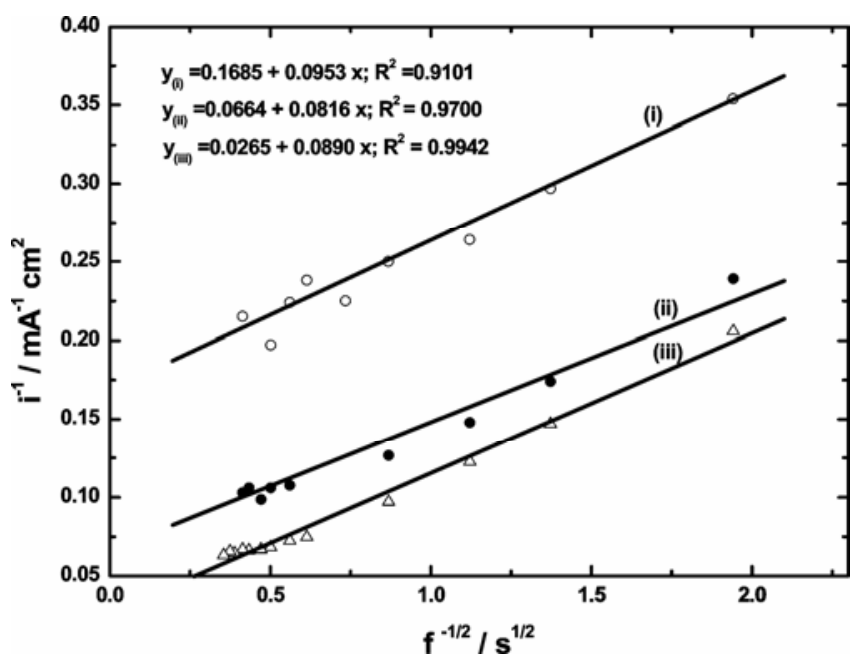

Figure 7. Koutecky-Levich plots for $\mathrm{H}_{2} \mathrm{O}_{2}$ reduction current at -0.50 (i), -0.60 (ii) and $-0.70 \mathrm{~V}$ (iii) in $0.5 \mathrm{M}$ $\mathrm{NaClO}_{4}+10 \mathrm{mM} \mathrm{H} \mathrm{O}_{2}$.

The RDE data were further analysed using (14) for irreversible reactions. ${ }^{18}$

$$
1 / i=\left(1 /\left(n F k C^{0}\right)\right)+\left(1 \cdot 61 v^{1 / 2} /\left(n F C^{0} D^{2 / 3} \omega^{1 / 2}\right)\right),
$$

where $k$ is rate constant. From the RDE data measured in $10 \mathrm{mM} \mathrm{H}_{2} \mathrm{O}_{2}+0.5 \mathrm{M} \mathrm{NaClO}_{4}$ electrolyte, current density measured at $-0.50,-0.60$ and $-0.70 \mathrm{~V}$ (figure 6(a)) were used to plot $i^{-1}$ versus $f^{-1 / 2}$ as shown in figure 7 (curves $i$, ii and iii). By extrapolation of the linear plots to origin $(\omega \rightarrow$ infinity), the values of rate constants $(k)$ are calculated as $3.01 \times 10^{-3}, \quad 7.85 \times 10^{-3}$ and $19.5 \times$ $10^{-3} \mathrm{~cm} \mathrm{~s}^{-1}$, respectively, at $-0.50-0.60$ and $-0.70 \mathrm{~V}$. The value of $k \theta$ calculated from amperometry at $-0.50 \mathrm{~V}$ is comparable to this value.

\section{Conclusions}

Electrochemical reduction of $\mathrm{H}_{2} \mathrm{O}_{2}$ was studied on a common alloy, namely, stainless steel in $0.5 \mathrm{M}$ $\mathrm{NaClO}_{4}$ aqueous solution of $\mathrm{pH} 5 \cdot 8$. Cyclic voltammograms consisted of single reduction peak at low concentrations of $\mathrm{H}_{2} \mathrm{O}_{2}$ and low sweep rates, whereas they consisted of two peaks at high concentrations of $\mathrm{H}_{2} \mathrm{O}_{2}$ and high sweep rates. This was attributed to a change in mechanism of reduction. This was supported by amperometric data, wherein a plot of current versus concentration consisted of two linear segments. The detection limit obtained was $5 \mu \mathrm{M} \mathrm{H}_{2} \mathrm{O}_{2}$. The RDE studies suggested that $\mathrm{H}_{2} \mathrm{O}_{2}$ reduction was diffusion controlled. 


\section{References}

1. Douglass W C 2003 Hydrogen peroxide medical miracle (Panama, Republic of Panama: Rhino Publishing)

2. Wilshire J and Sawyer D T 1979 Acc. Chem. Res. 12 105

3. Yeager E 1980 Progress in batteries and solar cells (Cleveland: JEC Press) vol. 3, p 238

4. Sies H 1985 Oxidative stress (London: Academic Press) p. 1

5. Sies H 1986 Angew. Chem. Int. Ed. Engl. 251058

6. Mukouyama Y, Nakanishi S, Konishi H, Karasumi K and Nakato Y 2001 Phys. Chem. Chem. Phys. 33284

7. Flatgen G, Wasle S, Lubke M, Eickes C, Radhakrishnan G, Doblhofer K and Ertl G 1999 Elctrochim. Acta 444499

8. Somasundrum $\mathrm{M}$, Kirtikara $\mathrm{K}$ and Tanticharoen $\mathrm{M}$ 1996 Anal. Chim. Acta 31959

9. Vazquez M V, de Sanchez S R and Schiffrin D J 1994 J. Electroanal. Chem. 374179
10. Cox J A and Jaworski R K 1990 J. Electroanal. Chem. 281163

11. Dodevska T, Horozova E and Dimcheva N 2006 Anal. Bioanal. Chem. 3861413

12. Arjsiriwat S, Tanticharoen M, Kirtikara K, Aoki K and Somsundrum M 2000 Electrochem. Commun. 2 441.

13. Greef R, Peat R, Peter L M, Pletcher D and Robinson $\mathrm{J} 1985$ Instrumental methods in electrochemistry (Chichester, UK: Ellis Horwood Ltd.)

14. Prabhu V G, Zarapkar L R and Dhaneswar R G 1981 Electrochim. Acta 26725

15. Somasundrum M, Tongta A, Tanticharoen $M$ and Kirtikara K 1997 J. Electroanal. Chem. 440259

16. Honda M, Kodera T and Kita H 1986 Electrochim. Acta 31377

17. Bard A J and Faulkner L R 1990 Electrochemical methods: Fundamental and applications (New York, USA: John Wiley \& Sons) p 218

18. Zurilla R W, Sen R K and Yeager E 1978 J. Electrochem. Soc. 1251103 